\title{
HEGEL PERSON, PROPERTY AND CONTRACT: LEGAL CONCEPTUAL STRUCTURE OF THE MODERN WILL
}

\author{
HEGEL PESSOA, PROPRIEDADE E CONTRATO: \\ ESTRUTURA CONCEITUAL JURÍDICA DA VONTADE MODERNA
}

\begin{abstract}
Agemir Bavaresco
Doutor em Filosofia pela Universidade Paris I Pontifícia Universidade Católica do Rio Grande do Sul (PUC/RS) Rio Grande do Sul / RS - Brasil abavaresco@pucrs.br
\end{abstract}

Christian Iber Doutorado em Filosofia - Instituto de Filosofia da Livre Universidade de Berlim Freie Universität Berlin (FUB/Alemanha) iber_bergstedt@yahoo.de

\begin{abstract}
In the theory of the Abstract Right, Hegel presents the structural concepts of civil and criminal law. The fundamental concepts of abstract civil law are the person, the property and the contract. The article defends the thesis that the State, by recognizing these structural normative concepts as established law, puts bourgeois society into action. In the first place, it deals with the discussion of the concepts of person and property; then, the relationship between the two concepts; and finally, it is considered the foundation of the Hegelian doctrine of contract and its peculiarities. The above-mentioned judicial concepts of civil law are reconstructed as structural moments of free will in bourgeois society. The methodology used is text analysis in the context of critical theoretical debates for the contemporary thematic update.
\end{abstract}

Keywords: Person. Property. Contract. State and bourgeois society.

Resumo: Na teoria do Direito Abstrato, Hegel apresenta os conceitos estruturais do direito civil e penal. Os conceitos fundamentais do direito civil abstrato são a pessoa, a propriedade e o contrato. $\mathrm{O}$ artigo defende a tese de que o Estado, ao reconhecer esses conceitos normativos estruturais como lei estabelecida, põe em ação a sociedade burguesa. Em primeiro lugar, tratase da discussão dos conceitos de pessoa e propriedade; depois, a relação entre os dois conceitos; e, por fim, é considerado o fundamento da doutrina hegeliana do contrato e suas peculiaridades. Os conceitos jurídicos de direito civil acima mencionados são reconstruídos como momentos estruturais da vontade livre na sociedade burguesa. A metodologia utilizada é a análise de texto no contexto de debates teóricos críticos para a atualização temática contemporânea.

Palavras-Chaves: Propriedade. Contrato. Estado e sociedade burguesa.

\section{Para citar este artigo}

\section{ABNT NBR 6023:2018}

BAVARESCO, Agemir; IBER, Christian. Hegel Person, property and contract: legal conceptual structure of the modern will. Prisma Jurídico, São Paulo, v. 19, n. 2, p. 225-244, jul./dez. 2020. http://doi.org/10.5585/prismaj.v19n2.17536. 


\section{Introduction}

In abstract law theory, Hegel presents the structural concepts of civil and criminal law. The fundamental concepts of abstract civil law are the person, the property and the contract. The article defends the thesis that the State, in recognizing these normative structuring concepts as an established right, puts bourgeois society into action.

First, it is a discussion of the concepts of person and property; then, the relationship between the two concepts; and finally, it considers the basis of the Hegelian doctrine of the contract and its peculiarities. The aforementioned legal concepts of civil law are reconstructed as structural moments of free will in bourgeois society.

\section{The person}

Hegel interprets the principles of abstract right and the judicial system in general from the theoretical view of the will. ${ }^{1}$ The concepts develop in the ambit of the personality of the free rational will in itself and for itself, which is objectively the universal will of the modern State. Hegel conceptualizes the abstract judicial person as a moment of free will that is in itself and for itself. In abstract right, the universal will of the State guarantees that the will in its elementary form as singular will of an atomistically isolated subject maintains its selfaffirmation as abstract freedom in the world (Hegel, 2010, § 34). ${ }^{2}$

This theoretical derivation of the will from the concept of person thus interpreted allows knowing that the subsumption under the abstract right turns a subject into a person that only concerns the aspect of the abstract universality of the will, that is, does not take into consideration the particular contents and finalities of the will. The concept of person denominates, in the first place, the atomistically isolated will of a subject in its abstract universality, since the judicial person is a private person. In the second place, in the concept of person lies the awareness of the subject of itself as a completely empty I, undetermined,

\footnotetext{
${ }^{1}$ Georg Wilhelm Friedrich HEGEL. Linhas Fundamentais da Filosofia do Direito ou Direito Natural e Ciência do Estado em Compêndio. Translation, notes, glossary and bibliography by Paulo Meneses, Agemir Bavaresco, Alfredo Moraes, Danilo Vaz, Curado R.M. Costa, Greice Ane Barbieri and Paulo Roberto Konzen, São Paulo: Loyola; São Leopoldo: Unisinos, 2010. German: G.W.F. HEGEL. Grundlinien der Philosophie des Rechts oder Naturrecht und Staatswissenschaft im Grundrisse. In: Theorie-Werkausgabe $(=$ TW) in 20 Bänden. E. Moldenhauer, K. M. Michel (org.). Bd. 7. Frankfurt am Main 1969-1971. The citations and references are provided from now on only with the $\S$ between parentheses. For citations of addends and manuscript notes $(\mathrm{N})$, TW 7 is cited with page number.

${ }^{2}$ Hegel conceptualizes right as the objectivation of the final activity of the universal, supra-individual will, which wants free will $(\$ \S 28,29)$, through which free will as such and, with that, also individual free will gains a being there $(\S 29)$. The concept of right says: Through the State's universal will, (individual) will must be able to want freely. The right is the "being there of free will" (§ 29) guaranteed by the State. Hegel's theory of will (\$§ 5-29) is characterized by the tension between the supra-individual concept of will and empirical individual will. The derivation of right is situated in this tense relationship between the two wills.
} 
self-referential, to which all the particular impulses of the will of the subject are linked. ${ }^{3}$ The equality of all the singular subjects, thinking about the concept of person, consists of the fact that they have such an abstract self-awareness. The concept of person expresses the inviolability and the authorization of the practical use of this aspect of freedom of will in its favor. ${ }^{4}$

The judicial capacity is directly linked to the concept of person, which constitutes the groundwork of the judicial order, since the subject's conscious self-relationality is the condition to attribute to it the imputability and responsibility for one's acts (Hegel, 2010, § 36). In its self-relationality, the subject may control him or herself and his or her drives of the will. As a person, the subject becomes subject with judicial capacity, that is, he or she is competent to possess rights and duties.

The judicial imperative says "be a person and respect the others as persons" (Hegel, $2020, \S 36$ ). The mutual recognition of the subjects as persons allows them in general firstly to be persons. Insofar as self-relationship of the person as such is not yet a judicial relationship, the mutual recognition of persons as free and equal is a judicial relationship that, at the same time, limits the inviolability of the will expressed by the person.

This is confirmed by the observation that in the mutual recognition of the subjects as persons lies an abstraction of the particularity of the will (Hegel, 2010, § 37). The particularity of the will is not be considered in the concept of person. It does not depend on the particular interests nor on the discernment and not even on the intention of the subjects, but on their judicial behavior in relation with itself and others.

Hegel stresses that the content of the judicial imperative is a judicial prohibition. Contrarily to the moral imperative, it is not necessary to make total use of what the right allows. The judicial imperative, be a person and respect others as persons, is, therefore, a

\footnotetext{
${ }^{3}$ Against Michael Quante's attempt to derive the concept of person from the concept of will in general (cf. idem. ,Die Persönlichkeit des Willens ' als Prinzip des abstrakten Rechts. Eine Analyse der begriffslogischen Struktur der $\$ \$ 34-40$ von Hegels Grundlinien der Philosophie des Rechts. In: G.W.F. HEGEL. Grundlinien der Philosophie des Rechts. Ludwig Siep (Org). (Reihe: Klassiker Auslegen. Otfried Höffe (org.). Bd. 9). Berlin: Akademie-Verlag, 1997, pp. 73-94) Friederike Schick affirms that the essential determination of the personality of being abstract self-consciousness does not coincide with the broader concept of self-consciousness of practical subjectivity, that is, the personality of the subject cannot be derived from the general determinations of human subjectivity. He understands that the judicial determination of the will as person conceptualizes will as abstraction of its moment of the particularity. This determination is not only an evident result of the rational self-determination of the will, but an imperative imposed from without. (cf. F. SCHICK. Der Begriff der Person in Hegels Rechtsphilosophie. Überlegungen zu den \$\$ 34-41 der ,Grundlinien der Philosophie des Rechts “. In: Recht ohne Gerechtigkeit? Hegel und die Grundlagen des Rechtsstaates. Mirko Wichke, Andrzej Przylebski (org.). Würzburg: Königshausen \& Neumann, 2010, pp. 71).

${ }^{4}$ Compared to the concept of personality, the person is the poorer concept, the abstract way in which the personality relates to itself, in which the abundance of the concrete determinations that it has in itself does not play any role (§35, § 37). The ambivalence of the concept of person between high and low ( $\$ 35 \mathrm{~N}$. TW 7, p. 94) resides in the fact that, on the one hand, it is a necessary moment of the will as personality, which must be judicially secured and, on the other, in it the will of the personality in its particularity has not yet been realized.
} 
judicial prohibition according to its content, which means that the prosecution of the particular interests of the subjects must have a place under the condition of "not harming the personality and what follows from it" ( $§ 38)$, to which, in addition to physical integrity, honor belongs as well. Therefore, with the statute of the person of the subjects is also excluded the direct violence between them, as well as the self-slavery of the subjects. Under the conditions of the abstract right, the social domination can only exist as objectively measured.

For short, it can be said that the self-reference and the intersubjective reference are constitutive of the concept of judicial person. ${ }^{5}$ The person is a social determination of the will; however, Hegel does not derive in a social mode the determinations of the person and of the property, but of the relationship with nature (things and objects) and thus denies the social character of these determinations, that is, he advocates a solipsistic will. The person realizes themselves and their freedom in relation to nature (things and objects) in the form of possession and property. Hegel develops, therefore, possession and property within the structure of a theory of solipsistic will (Hegel, 2010, § 41).

\section{The property}

Hegel distinguishes property from possession. Property is the right of having something at disposal differently from the mere practical having something. Property does not mean, then, only the relationship between a person and an object, but the excluding relationship of this person from the interference of other persons in relation to a certain object, that is, an exclusive social relationship. Property is the exclusive right of disposal of a person in relation to the things that constitute the exclusive sphere of their freedom (Hegel, 2010, $\S$ 45, 2010). Nevertheless, Hegel does not consequently firmly maintain these determinations, since he thinks about possession, that is, he eliminates the specific social dimension of property. Hegel's solipsistic theory of the will may be considered as the cause of this ambivalence, which will be pursued further. ${ }^{6}$

\footnotetext{
${ }^{5}$ Cf. Kurt SEELMANN. Selbstwiderspruch als Grund für Rechtszwang, Fremdbestimmung von Lebenssinn? In: Anfang und Grenzen des Sinns. Brigitte Hilmer, Georg Lohmann, Tilo Wesche (org.). Weilerswist 2006, pp. 250-263, esp. pp. 260-263.

${ }^{6}$ Subject of person and property is the will as "excluding singularity" ( $\left.\$ 34, \S 39\right)$. Hegel would have to understand this singularity as excluding in relation to another singularity and, with this, as a social singularity. However, firstly, he understands it as a negative relationship with another thing (§ 13). The relationship to other subjects, then, has-as Hegel himself observes - a marginal status in his doctrine of person and property ( $\$ 29$ N. TW 7, p. 82 s., $\S 38$ N. TW 7, p. 97). Because of the solipsism of his theory of will, Hegel neglects the side of the social exclusion of the property and conceptualizes it unilaterally as the realization of the freedom of the person concerning one Thing. About the concealment of intersubjectivity in Hegel's conception of will and its reasons, cf. Michael THEUNISSEN. Die verdrängte Intersubjektivität in Hegels Philosophie des Rechts [The repressed intersubjectivity in Hegel's philosophy of right]. In: Dieter Henrich, Rolf-Peter Horstmann (org.). Hegels Philosophie des Rechts. Die Theorie der Rechtsformen. Stuttgart 1982, pp. 317-381, esp. pp. 329-335. Cf. also Karl Heinz ILTING. Rechtsphilosophie als Phänomenologie der Freiheit. In: Hegels
} 
It is something crucial Hegel's intellection that in property the mainstay is not factsuch as possession - of being a means to the satisfaction of needs, but that the property has its end within itself, precisely in the exclusion of other persons in the domain of these things. Thus, the judicial aspect of possession turned into property lies in it (Hegel, 2010, $§ 45$ Addend).

Hegel affirms that property, contrarily to the possession of utile things for usage, is the exclusive sphere of the free will indifferent to the satisfaction of needs. However, Hegel is not attentive to the relationship between possession and property, insofar as he does not think about both as two sides of a relationship that he conceptualizes in its whole as a relationship of possession. Thus, he considers necessary, in the determination of property, to treat in details the taming of possession, the use and the utility of a Thing. ${ }^{7}$

The division of the chapter about property in possession, usage and exteriorization shows the insufficient distinction between property and possession, since it is made throughout "their most precise determinations in the relationship between the will and the Thing” (Hegel, 2010, § 53). Hegel's deficit in the determination of property lies in the fact that, despite not identifying property with possession of a useful Thing, which has its finality in its usage, he, however, claims that property is in a positive relationship with the use and the utility of a Thing. The property is realized in the use of the Thing, then, is the true sphere of the person's freedom, which enables and permits them to effect the satisfaction of their needs. $^{8}$

On the other hand, and contradictorily to that, it is experienced, in the first place, that without property the Thing cannot be used; thus, the latter is subordinated to the former (Hegel, 2010, § 59 Obs., 2010), and, in the second place, that the use is not in any sense the finality of property and the main point of property is not lost, if the proprietor does not use the useful things that they have at their disposal (Hegel, 2010, § 62). In the third place, it is

Philosophie des Rechts. Die Theorie der Rechtsformen. Dieter Henrich, Rolf Peter Horstmann (org.). Stuttgart 1982, pp. 233.

${ }^{7}$ Márcio Schäfer firmly maintains this ambivalence as a decisive deficit in Hegel's theory of property: "Regardless of the fact that Hegel separates the determination of property from possession or needs, that is, he does not determine the property in relation to the needs, he does not consistently firmly maintains this distinction [between person and property]" (Márcio SCHÄFER. Bürgerliche Gesellschaft und Staat. Zur Rekonstruktion von Marx ' Theorie und Kritik des Staates. Würzburg, 2018, p. 216. Cf. também Ina Schildbach. Armut als Unrecht [Pobreza como in-justica]. Bielefeld 2018. p. 121)

${ }^{8}$ Hösle agrees with Hegel's view of property in saying: "The finality of the property is the use" (cf. Vittorio HÖSLE. Moral und Politik. Grundlagen einer Politischen Ethik für das 21. Jahrhundert [Morality and Politics. Fundamentals of a Political Ethic for the Twentieth Century]. München 1997, p. 825). He ignores the separation between the use and the peculiar disposition given by modern property, which corresponds to the duplication of all the goods of market economy in use value, on the one hand, and exchange value, on the other. 
seen that if even the proprietor does not show interest in the use of things, others that may use them well cannot get hold of them (Hegel, 2010, § 62 Obs.). What is left, then, is little of the positive relationship between property and satisfaction of needs. With that, Hegel emphasizes the difference between property and possession, which he constantly denies.

The item about exteriorization ${ }^{9}$ of property leads to the contract (Hegel, 2010, §§ 6570). Hegel does not sufficiently distinguish property from possession and, thus, reduces property to the use of the Thing. It is worth asking how the Thing can still be exteriorized when it has been consumed. An answer would be that we can consume a part of the Thing and exteriorize another part, that is, we can have different relationships between will and Thing. The fundamental category of abstract right is the "possibility" (Hegel, § 37 Addend, TW 7, p. 96, 1971). However, if the sequence of different forms of relationship of the will in relation to a Thing were only a possible sequence, the necessity of exteriorization of property claimed by Hegel could not be explained (Hegel, 2010, § 41).

Under the condition that all the Things have become property, the acquisition of property can no longer be limited to the taking of possession nor can the property be exhausted in relation to the use of the Thing. Then, I can only acquire property insofar as I exteriorize myself of my property. In the universalization of the property lies the need of its exteriorization.

Hegel thinks that a contract of salary is possible without turning the worker into property of another, if the former who exteriorizes his or her workforce to another only offers his or her workforce to the latter for "a usage limited in time" (Hegel, 2010, § 67). The crucial aspect of this restriction is evidenced by the contrast between day workers and slaves (Hegel, $\S 67$ Addend, TW 7, p. 145, 1971). Hegel understands that, in paid work, the exteriorization of the workforce of the worker and the buying and usage of this force by the proprietor coincide. In other words, the utilization of the worker's workforce by the capitalist and the exteriorization of the workforce by their sale by the paid worker are two sides of the same coin. The worker receives the value of his or her workforce whereas the capitalist uses this workforce. The concept of property in Hegel envisages that it is the paid work relationship that is given by the universalization of property. This already foreshadows what will be said further by Marx.

For short, the theory of property in Hegel obfuscates the difference of the historical genesis of property by the taking possession and the judicial validation of property. It is the

\footnotetext{
${ }^{9}$ We have translated "Entäußerung" by "exteriorization". In the judicial sense, the term "alienation" is also used.
} 
decline of feudalism and the emergence of bourgeois society that affirms itself in its place and of the capitalism already prefigured in the historical scenery. The paradigm of Hegel's theory of property is based on the property of the land. In modernity, the private property of land is separated from its economic usage, constituting itself in free private property. That is, the power of having judicially acknowledged private property of people over land at one's disposal is separated from the particular economic conditions of its usage. This is the result of the dissolution of the social feudal order, in which the property of the land was the center of the economic, social and political organization of society. ${ }^{10}$ The property of the land acquires thus the character of the "free, total property" (Hegel, 2010, § 62), since a right to tribute is established (renting, lease etc.) for residency (dwelling) and usage (production of foods, raw materials, transportation routes). It becomes, thus, a means to increase money and a sphere of popular investment of capital.

\subsection{Relationship between person and property}

Hegel derives the concept of property from the relationship of the person with nature or external object. Thus, he inverts the logical order of property and person. Hegel knows that property cannot be derived only from the relationship of the will to nature or external object. The finality of property is not to possess an object to have with it the means of its selfpreservation, but the finality is within itself (Hegel, 2010, $\S 45$ Obs.), that is, with the private property all utility depends upon property. It is not because of the particular interest in an object that it is appropriated (= possession), but regardless of the particular utility of an object, it is about the sovereign right of disposal of the free will over an object (ius de re perfecte disponendi), which excludes other subjects and, therefore, is out of the reach of other individuals and the public sphere. ${ }^{11}$ With the judicial institution of the property, the equation of utility of the property becomes universally valid, so much so that all utility depends upon the property acquired. If this equation works for the proprietors in a positive or negative sense is determined by the extension and quality of the property.

\footnotetext{
${ }^{10}$ The transformation of feudal property in modern private property was associated to the liberation of the servile peasants and the expropriation of the peasants who worked freely in the feudal property, passing to the arising of the emerging proletariat. 11 "The exterior that is mine is that in whose use disturbing myself would be a lesion, although I was not immediately in possession of it (not possessor of the object." (Immanuel KANT. Metaphysik der Sitten [Metafísica dos costumes]. In: Werke in zwölf Bänden. Wilhelm Weischedel (org.). Frankfurt am Main 1968 Vol. VIII, I § 5, BA 62).
} 
It is not the will as person that makes property necessary, but, inversely, the specific determination of the form of the will as person is founded on property. The opposition of the interests of the social subjects, which is expressed in the judicial imperative "be a person and respect others as persons" (Hegel, 2010, § 36). This judicial imperative is founded, then, on the conflict of interests of the subjects as proprietors. What would be another reason to impose respect upon one another as persons if not due to their constituted interests, which constantly conflict? Hegel affirms: "Property: collision, envy, enmity, conflict, wars" (Hegel, § $46 \mathrm{~N}$. TW 7, p. 110, 1971). The imperative of mutual recognition of the subjects as persons is based on their conflict of interest as proprietors. Therefore, the conflict is not eliminated by that imperative, but only moved to a civil form guaranteed by the State.

In the item about the judicial person, Hegel determined the concept of person only in abstract terms: person is the determination of the formal universality of the will that is free for itself of an isolated singular subject, which does not take into consideration its particular contents and finalities (Hegel, 2010, § 35). In this case, the concept of person expresses its inviolability and, then, the authorization to be applied with the universality of the freedom of the will.

In the theory of property the correct order of property and person now becomes valid due to the fact that Hegel here concretizes the abstract preliminary outline of the concept of person. Only from the being proprietor of the subjects becomes retroactively comprehensible because the will emerges as the will of an isolated singular to which Hegel attributes the concept of person in the item about the judicial person. Finally, the concretizations of the concept of person that Hegel makes in the chapter about property show that with the concept of person the property relationship about the things passes to the self-relationship of the subjects (Hegel, 2010, $\S \S 47,48,57)$. One person is one subject that no longer belongs to no one, only to oneself, who has an exclusive relationship of possession or property with oneself, with one's body and mental faculties.

The internalization of the relationship of property in relation to the Things in the selfrelationship of the subject in the concept of person renders comprehensible that the poor and helpless human being, incapable of subsistence in the sense of civil right, does not belong to no one but themselves. The individual is defined as one who is "objectively" utile and utilizable in its person, that is, their capacity of work as property. From the point of view of property right, as Hegel says, it indeed appears as a "judicial contingency," "what and how much I have" (Hegel, 2010, § 49). That is, the quality and the quantity of the property is a judicial contingency. This may damage the person, but it does not constitute the person. In 
bourgeois society, the person with no property has an absolute value. An unshielded human being also has human dignity, although they are a person only abstractly. Poverty may not cause indignation in civil society, since there is here a reductionism of the concept of person in its abstract, private dimension. ${ }^{12}$

This also concretizes the judicial imperative: the conflicts of interests of the social subjects - it does not matter what and how much they possess as proprietors, whether it is earth, goods/active of capital or work - they must be realized with the recognition of property and person.

The principle of property may come into conflict with the finality of reproduction, since this is not its finality. Then, the State intervenes to guarantee the individual reproduction of the person. The State needs to resolve the contradiction of property when the quantity of quality of the property is not sufficient to feed a person; property, however, has to be artificially increased for it to be serviced by the reproduction of the person. In dealing with the right of necessity [Notrecht] (Hegel, 2010, § 127), Hegel puts the right to life above the right to property. With the finality of saving lives, the right to property may even be violated (Hegel, § 127 Addend, TW 7, p. 240s., 1971).

For short, Hegel's considerations about the concept of person suggest that the category of person presupposes the concept of property as being the first category of civil right, without which the judicial concept of person is not comprehensible. It is worth countering Hegel in that the concept of person as a principle of abstract right presents a social determination of the will. This presupposes determined social conditions that render necessary this social form of the will, that is, being a person is not the result of the concept of will in general, but of the social determinations of private property in a determined economic system. The private person is, therefore, a determined social form of the will in a social-historical context in which private property dominates.

\section{The contract}

Hegel's theory of contract may be affirmed to be among the best products of his intellectual career. The contract is the truth of property insofar as in it is rendered explicit the intersubjective relationship that is implicitly contained in the property as a being there

\footnotetext{
${ }^{12}$ Hegel thematizes a broader concept of person under the title of "personality" (cf. $\S 35$ addend, TW 7, p. 95). However, the concrete personality of the will cannot be developed in the sphere of abstract right.
} 
exclusive of the will of the person. ${ }^{13}$ In the contract, the property is acquired only "through mediation of another will" (Hegel, 2010, § 71). Therefore, Hegel distinguishes between the acquisition of property through the taking possession and acquisition of property through contract. This is characterized by the fact that I am dependent on the will of others, a will that is in the object to be acquired, which I do not have but need. The object of the contract is not only a Thing, but the objective correlative of another will. Therefore, the acquisition of property through contract is only realized if the other will is retrieved from its object.

According to Hegel, the contract is necessary in its reason of right, since it is an end in itself such as property. In it emerges a common will, but not as common consciousness understands it, that is, due to the mutual benefit of the participants, but to determine the conditions in which the contractors transfer their consumption goods. The presupposition of the contract is that to each party of the contract something that the other part does not have, but needs, belongs. Thus, they have to agree with the terms and conditions of how they may reciprocally access the property of the other part. The proprietors depend one on the other at the same time, which is why they agree in the contract about what they have to externalize from their property to obtain the property of the other.

Thus, Hegel transforms the recognition of the contractors as persons and proprietors, which becomes necessary due to its dependency founded on the mutual exclusion in a positive Thing and interprets it [the recognition] as a decisive moment of the universalization of the subjective will (Hegel, § 71 Addend, TW 7, p. 155, 1971).

In the foundation of his theory of the contract, Hegel conceptualizes the contract as a contradiction as a process of mediation. It is a contradiction, since in the contract "I am and remain proprietor" (Hegel, 2010, § 72), because I am relieved of my Thing. How can I be and remain a proprietor insofar as I cease to be a proprietor? The question is how to mediate this contradiction.

Hegel interprets the contradiction discussed of the contract as self-exteriorization of the will of the proprietor, who has "the character of an alteration [Veranderung: become other]". ${ }^{14}$ The common ground or the identity of the wills in the contract is not only an objectivation of the exclusive possessivity [Meinigkeit] of my will in a Thing as in the property, but a self-exteriorization of my exclusive will of necessary being proprietor under the conditions of universalization of property. This is a self-externalization that alters my

${ }^{13}$ Cf. Vittorio HÖSLE Hegels System. Der Idealismus der Subjektivität und das Problem der Intersubjektivität. Bd. $2 .:$ Philosophie der Natur und des Geistes. Hamburg: Meiner, 1988, p. 500.

${ }^{14}$ Cf. Michael THEUNISSEN. Die verdrängte Intersubjektivität in Hegels Philosophie des Rechts [A intersubjetividade reprimida na filosofia do direito de Hegel], 1982, p. 362. 
status of being proprietor, because with it I associate myself to the community of proprietors that exchange property as one among the others. The contract constitutes with it the "unity" (Hegel, 2010, § 73) of wills of proprietors that reciprocally exclude themselves, wherein they renounce their wills of excluding proprietors and, at the same time, maintain the will of the proprietors.

The contradiction of the contractual relationship finds its progressive form in the mediation that all remain proprietors, ceasing to be proprietors and at the same time becoming proprietors (cf. Hegel, 2010, § 74). In the contract all become proprietors, relieving themselves of the particular Thing, recovering what is universal in this Thing: its value (cf. Hegel, 2010, § 77).

Although the contract is of decisive importance in the genesis of the objective universality of the will of the State, it presents a deficit: because the contracting wills behave among themselves as private persons, the contract is based on, firstly, in the arbitrariness of the contracting parties; secondly, the identity realized is only one common ground produced by the contracting parts, not a universality that precedes the singular will; and, thirdly, the mediation occurs only in a "singular exterior Thing" (Hegel, 2010, § 75). ${ }^{15}$

For these reasons, marriage and State, according to Hegel, cannot be conceptualized in terms of the theory of contract (Hegel, 2010, $\S 75$ Obs.). Hegel aims to develop the 'identity that is in itself' (Hegel, 2010, § 81) of the State that is presupposed in the contract. It is developed in the State as the objective universality of the will. Because the common ground of the contract presupposes the identity of the universal will of the State, it cannot be grounded in contract. We would be entering the vicious circle of presupposing the State in the contract, whereas the State should emerge through the contract. In other words, the argument is the following: (i) The State should emerge through the contract. (ii) The State, however, is the instance that guarantees the contract. (iii) Therefore, the State cannot depend on the contract. In the explanation of the State through the contract there is a vicious circle because the State cannot be explained by the contract, once the State is presupposed in the contract. That is, the explanation should already make use of that which should be explained.

The fact that the contract presupposes the coercive power of the State is shown in the transition to un-justice [Unrecht]. Once the contracting parts only combine selectively to form a common will, they remain particular wills that may, thenceforth, put themselves against

\footnotetext{
${ }^{15}$ Ina SCHILDBACH stresses that the contract presents the "constitution of a social connection" (p. 124) of mutually excluding proprietaries "that lack effective universality" (p. 126). Idem. Armut als Unrecht [Poverty as in-justice]. Bielefeld: transcript Verlag, 2018.
} 
their common will and against what is "right in itself" (Hegel, 2010, § 81), that is, against the legitimate state judicial order in general.

The reason for which the contract is celebrated, the particular interest in the property of the other party, is also the reason for which the parts do not necessarily want to execute the contract. Thenceforth, it does not reside in the form of the participants' power to guarantee its common ground, but because they should firm their interdependency. Once the possibility of its violation is inherent to the contract itself, the contracting parties are dependent on a sovereign power over them that renders its common contractual will effectual.

The theoreticians of the State of the Modernity face the problem of assuming, on the one hand, that individuals are free to act arbitrarily and, on the other hand, to think about that freedom along with a state authority that may guarantee the coexistence of the free individuals by right and law. Hegel rejects the theoretical attempts of the contract to solve this problem. Hobbes's solution is a State that, as sovereign coercive force, externally restricts the freedom of the individuals, but demands from the reason of the individuals no more than the recognition of the need of this restriction for the maintenance of peace. This contrasts with Rousseau's solution of thinking about the power of the State as volonté générale and to form the private will to that universal will. Hegel sympathizes with Rousseau's solution, but he, however, rejects it, since here the universal will arises from the private will theoretically from the contract and remains dependent on it (Hegel, 2010, § 258 Obs.).

Hegel's strategy is elevating the individual will to the universal will through the educational process so that the right and the State, so to speak, depose their violent aspects. The abstract right is yet coercive law (Hegel, 2010, § 94). However, already with the transition of the abstract right to morality, the stress goes from the external sanction to the moral constitution of the universal will (Hegel, 2010, § 103). Finally, in Hegel's concept of State, it is the morality of the citizens - which became a practiced custom - that keeps the State together and fills it with ethical spirit so that the power of the civic disposition, which becomes a habit (Hegel, 2010, § 268 Addend), the authority of the State is replaced. Indeed, it is irrefutable that the citizens maintain and consolidate the civic order with their dispositions. Nevertheless, civic morality and the State's exteriorly obligatory power are bound together. Hegel thinks about an ideal State wherein violence does not need to be imposed for itself insofar as the State lives on the disposition of the ethical spirit of its citizens, that is, a good disposition of the ethical spirit of the citizens renders superfluous the violence of the State. This is dependent on a new formation or education of the citizens, then, this ideal does not 
become effective since the State cannot guarantee the resolution of the contradictions of the bourgeois civil society.

\subsection{Particularities of Hegel's theory of contract}

Hegel divides the contracts into formal and real contracts, that is, in contracts of donation and contracts of exchange (Hegel, 2010, § 76). ${ }^{16}$ The contracts of donation are at deficit in comparison with the contracts of exchange, because only the latter imply a reciprocal transference of property as the contracts of donation are unilateral transference of property. The contracts of donation include the borrowing of Things, borrowing without interest rates and free custody (depositum). To the contracts of exchange belong, in addition of the exchange itself the contracts of purchase, rent, salary, service and labor as well as the order of mandate.

There is also a third group, the "consolidation of a contract (cautio) by pledding" (Hegel, 2010, § 80). Here a grant is given to a contractor, who acts in the first place against the failure of contractual prestation of the other contractor in the form of credit. In the German civil law, these contracts are distinguished from the real contracts as mandatory contracts or promise-contracts of the contracts of right of things [dingrechtliche Verträge].

Hegel's preference for real contracts takes him to advocate laesio enormis [excessive violation of contract] as judicially rational (Hegel, 2010, § 77). Once it is constitutive for the real contract that I continue to be a proprietor as much as that I cease to be a proprietor, according to Hegel, the equivalence of value of exchanged Things has to be preserved. With his consideration, Hegel restricts a private autonomy understood as purely formal and pleads for a material contractual justice.

At the same time, with the resource to this judicial-Roman and medieval determination Hegel contradicts his own contractual model, which arises from the deal of two wills as the doctrine of laesio enormis with which the usurer transactions should be prevented, presupposes a third instance, the equivalence of value of the services so much so that not only the contractual deal should be secured, but also the basis of material value of the contract. From this particularity results that, from Hegel, there can only be limited debt contracts, so called mandatory contracts, which became obsolete with the substitution of usury with credit as a means of the industrial and commercial capital.

${ }^{16}$ In his classification of contracts Hegel is guided by Kant's classification of the contracts. In: Metaphysik der Sitten [Metphyísics of customs]. idem I § 31, AB 118s. 
The modernity of Hegel's theory of contract is seen in the fact that, for Hegel, the alternation of property already occurs with the contractual deal, therefore, with the conclusion of the contract, not only with the performance of the execution of the contract, that he conceptualizes as mere alternation of possession (Hegel, 2010, § 78). He confirms this point of view drawing upon the Roman judicial institute of stipulation, in which the contractual expression of the will is done with the formal exposure (Hegel, 2010, § 79). With the principle that the transference of property does not happen primarily with the transference of possession, Hegel follows the Civil Code.

With this view of the judicial validity of the contract, Hegel opposes the foundation of the contract in the "mere promise" (Hegel, 2010, $§ 79$ Obs.). ${ }^{17}$ Hegel grounds his view as a critique of Fichte, for whom the mandatory character only begins with the beginning of the execution of the contract by the other party for me, since it can never be discarded that the other is not serious, from which the mandatory character of the execution is more of moral than judicial character (id.). ${ }^{18}$ According to Hegel, Fichte's view presupposes a general mistrust and indeed eliminates the judicial mandatory character of the contract, since with a step-by-step execution, "the judicial element of the contract would be put in the bad infinity, in the ad infinitum process" (Hegel, 2010, § 79 Obs.).

Behind Hegel's critique of Fichte is his critique to the must be without objectivity, which remains in the moral interiority. The transference of property is a must be that has not been rescued yet. Hegel, on the contrary, affirms that, with the transference of property in the formalization of the contract is grounded a judicial mandatory character for the real execution. The transference of possession is judicially bound to the transference of property and not the other way round. In the German civil service, this corresponds to the principle of abstraction, the distinction between business of obligation and operation of sale [Verfügungsgeschäft].

It is interesting to notice that, in his theory of contract, Hegel contradicts his own concept of proprietor according to which the property is linked to the possession and the use of the Thing, so that it could have been expected that, for him, the property only passes with the transference of possession. But Hegel's theoretical view of the contract is revealed, at this point, wherein it contradicts his own concept of property, as more modern. The authority of the State secures that the judicial right to execution of the contract is not limited to the mere

\footnotetext{
${ }^{17}$ Cf. Adolf REINBACH. Die apriorischen Grundlagen des bürgerlichen Rechts. [Os alicerces a priori do direito civil] In: Jahrbuch für Philosophie und phänomenologische Forschung 1 (1913), p. 685-847.

${ }^{18}$ Cf. Johann Gottlieb FICHTE. Beiträge zur Berichtigung der Urtheile des Publicums über die französische Revolution [Contribuições para a correção das opiniões públicas sobre a Revolução Francesa] (1793). In: Fichtes Werke Bd. VI. Immanuel Hermann Fichte (Org). Berlin 1971, p. 111s.
} 
must be (intention), but be complemented by the effective execution of the contract, that is, the contracts can be effectuated in courts according to specific procedures.

With his critique of the foundation of the contract in the promise and its recourse to stipulation, Hegel rejects the judiciality of informal contracts evidently because of its incalculable consequences, then due to reasons of judicial security (Hegel, § 79 N. TW 7, p. 164s., 1971). Contrary to the judicial culture practiced in the developing bourgeois society, Hegel advocates a Roman judicial formalism. Carl Friedrich von Savigny shows in the stipulation that in antiquity it was a strictly formalized judicial norm, that in Central Europe since the Middle Ages it became an informal contract that became actionable. ${ }^{19}$ The formless and actionable contract also prevailed in the German Civil Code since 1891. The formlessness, the freedom and the judiciality of the contract also became an important judicial institution of the developing free market economy in the Napoleonic Code (1804). ${ }^{20}$

\section{Final considerations}

It can be concluded that, in the concepts of property, of the person and the contract it is demonstrated that the will constituted in the bourgeois society follows a path marked by the principles of the abstract right. Hegel turns against the opinions of common sense that intend to find in the concepts of person, property and contract something useful to their immediate well-being. On the contrary, being a person has no implication with the subject's particular needs or desires, but only with the fact that the will, in its universality, is abstractly valid to itself; the difference between possession and property shows that property is not a means to meet needs, but the right of disposition over things that exclude other subjects; the contract is not an instrument to produce mutual or common benefit, but the means to maintain the contradiction of the property when the other is useful to me, thus building a bridge over the opposition of interests.

Hegel considers these concepts of abstract right as something rational, but the affirmation that a Thing is rational cannot imply that it is systematically in a negative relationship with someone's benefit. This affirmation contains, in our opinion, then, a theoretical deficit. The justification of the concepts of person, property and contract as rational occur through their derivation from the concept of free will. They are presented as realizations

${ }^{19}$ Cf. Carl Friedrich VON SAVIGNY. Das Obligationsrecht als Theil des heutigen Römischen Rechts. Bd. 2. [O direito das obrigações como parte do direito romano contemporâneo. Vol. 2]. Berlin 1853, p. 240.

${ }^{20}$ Cf. Gerald HARTUNG. Vertrag II. In: Karlfried Gründer, Gottfried Gabriel (org.). Historisches Wörterbuch der Philosophie. Bd. 14. Berlin 2001, pp. 965-975, esp. p. 974. 
of free will, then, they correspond to free will. But the transition of free will to the person, property and contract supply only the contradictory proof that free will is realized in its limitation through right. This contradiction has its groundwork in the fact that Hegel does not sufficiently analyze these judicial concepts in their determination as social form. Being a private person, being a proprietor and establishing contracts are social determinations of the will and cannot be derived from free will itself. This deficiency of derivation is particularly evident in the relationship between person and property. Since the determination of the subject as person presupposes property, that is, the means of reciprocal negation of the existence of the subjects, the derivation of property from the person is wrong. It is not the person, but the property that is the first category of abstract right. This shows that property, person and contract do not correspond to free will in itself and for itself, but to the social relationships in which will is active. The rational core of Hegel's derivation of the concepts of abstract right of free will is that they not only are factually recognized by the subjects of bourgeois society, but are also considered worthy of recognition since they correspond to the will of subjects wanting to succeed within bourgeois society.

The Hegelian theory of the judicial concepts of person, property and contract as constitutive of the modern right and structuring of the bourgeois society is a jus-philosophical justification of the modern judicial system. In bourgeois society, the will only exists as proprietor, person and contracting party. With the help of these concepts, the will is syllogized with the bourgeois society by the State. Yes, it must be said: with the aid of these concepts, the State puts, firstly, the bourgeois society in action, and inversely the latter makes the former necessary as modern State. Thus, already in the beginning of Hegel's Philosophy of Right it is shown that bourgeois society is realized by its judicial formation and, then, could not have existed without the State. The State and the bourgeois society reciprocally presuppose one another, that is, both necessarily belong one to the other and only together they form a whole. One of Hegel's most important elaborations is that bourgeois society is not a whole that reproduces itself, but it needs the State for its functioning. With the concepts of right, the State not only puts bourgeois society in action, but the latter also has no substance without the former's intervention into it.

We would like to conclude our investigation with a methodological observation. Hegel, in the Philosophy of Right, presents the conceptual development of Right and not the historical development of the judicial society. Hegel applies the same method as in Logic, in which he provides a speculative reading of the forms of being and thinking insofar as the concept 'creates' the logical categories. As much as Hegel in the Logic advocates a 
metaphysic of the performative self-movement of the concept, also in the Philosophy of Right he sustains a metaphysic of the development of free will. Just as in the Logic the concept that is in itself and for itself is the principle of the logical development of the categories of being and thinking, likewise in the Philosophy of Right the will that is in itself and for itself free is the principle of the derivation of the jus-philosophical categories of the abstract law through the morality to the ethicity of the State. In the Logic, the concept that is in itself is the principle of the categories of being, the concept that is for itself is the principle of the determinations of the reflection of the essence and the concept that is in itself and for itself is the principle of the logical categories of the concept of the thinking subjectivity and world objectivity. ${ }^{21}$ In the Philosophy of Right, the will that is in itself free is the principle of the abstract law (person, property, contract), the will that is for itself free is the principle of morality and the will that is in itself and for itself free is the principle of the ethicity and the State. As much as Hegel in the Logic makes the concept the form of thinking that assesses the specific identity of the Thing in a metaphysical principle of deduction in the logic, also in the Philosophy of Right he transforms freedom as universal form of the will into a metaphysic of the will underlying to the system of right:

Every step in the development of the idea of freedom has its peculiar right, because it is the embodiment of a phase of freedom. When morality and ethical life are spoken of in opposition to right, only the first or formal right of the abstract personality is meant. Morality, ethical life, a state-interest, are everyone a special right, because each of these is a definite realisation of freedom(Hegel, 2010, $\S 30$ Obs.).

From the will that is in itself and for itself free in the Hegel, 2010, $\$ 27$, according to which this "is, in principle, the free will that wants will free," 22 Hegel makes the transition for the right in the Hegel, 2010, $\$ 29$, according to which the "right" is the "being there of free will." Free will, which has as its object the very free will, is the instance that gives free will the license of its being there. Rationally considered, this instance is the modern State, which guarantees to free will the sphere of right or the many spheres of right within which free will is allowed to want. Hegel, however, understands this state of things in a way that he turns free will that is in itself and for itself into a metaphysical principle of the derivation of the other forms of right, from which the State emerges as a result only in the end. The transition of the will to the right does not result from the concept of will, but presupposes social relations in

\footnotetext{
${ }^{21}$ Cf. Introduction. General division of logic. In: Hegel, G.W.F. Ciência da Lógica. 1. A Doutrina do Ser. Translation: Christian G. Iber, Marloren L. Miranda and Federico Orsini. Petrópolis, Rio de Janeiro: Vozes, 2016, pp. 62-67.

${ }^{22}$ In $\S 27$ Hegel conceptualizes free will with the title "idea of will" as unity of the concept and reality of the will, of the free will in itself and the free will for itself.
} 
which the will is constantly at risk of being denied, that is, depends on an instance that gives it the license to want.

For short, the modern will constituted by the right is not understood by Hegel as a product of the historical-economic organization of certain social relations by the State. On the contrary, it is as if free will gave itself - in the various judicial institutions, in the moral and ethical-state relations - a being there that corresponded to its concept and were, therefore, rational. The truth is that the modern will is constituted by the abstract right, by the moral relations and by the ethical-state institutions, which Hegel also brings to bear. Indeed, what occurs in Hegel's Philosophy of Right is the realization of a contradictory unit of the scientific explanation of the judicial, moral, and ethical-state concepts that form the will and its respective legitimation as if they were rational, since all are presented as products deriving from the will that is in itself and for itself free.

In other words, Hegel's theoretical deficit in his Philosophy of Right in general is that the judicial concepts correspond to the abstract will: The property and the person turn the will into an abstract will. Hegel posits that the judicial concepts are products of free will that is in itself and for itself. The same is repeated today when it is affirmed that the State and society correspond to the essence of the human being as if they were an emanation of its essence. Hegel does so in his jus-philosophical description, that is, the judicial system of the modern State is the product of the development of the free will in the speculative metaphysical sense. The truth is that the modern will is constituted by the abstract right and by the moral relationships and the ethical-state institutions, that is, the property and the person constitute the social determination of modern will. Hegel's legitimating presentation confirms that the person and the propriety are products of the will that is in itself and for itself free.

\section{References}

EICHENSEER, Georg. Die Auseinandersetzung mit dem Privateigentum im Werk des jungen Hegel. Privateigentum als gesellschaftliches Herrschaftsverhältnis in der politischen Philosophie des jungen Hegel in den Jahren 1793-1805. Gießen: Focus, 1989.

FICHTE, Johann Gottlieb. Beiträge zur Berichtigung der Urtheile des Publicums über die französische Revolution (1793). In: Fichtes Werke Bd. VI. Immanuel Hermann Fichte (org.). Berlin: De Gruyter, 1971.

HARTUNG, Gerald. Vertrag II. In: Karlfried Gründer, Gottfried Gabriel (org.). Historisches Wörterbuch der Philosophie Bd. 14. Basel: Schwabe, 2001, pp. 965-975. 
HEGEL, G.W.F. Ciência da Lógica. 1. A Doutrina do Ser. Equipe de tradução: Tradutores: Christian G. Iber, Marloren L. Miranda e Federico Orsini. Coordenador: Agemir Bavaresco. Colaboradores: Michela Bordignon, Tomás Facic Menk, Danilo Costa e Karl-Heinz Efken. Petrópolis, Rio de Janeiro: Vozes, 2016.

HEGEL, Georg Wilhelm Friedrich. Grundlinien der Philosophie des Rechts oder Naturrecht und Staatswissenschaft im Grundrisse. In: Theorie-Werkausgabe in 20 Bänden. E. Moldenhauer, K. M. Michel (org.). Bd. 7. Frankfurt am Main: Suhrkamp, 1969-1971.

HEGEL, Georg Wilhelm Friedrich. Linhas Fundamentais da Filosofia do Direito ou Direito Natural e Ciência do Estado em Compêndio. Tradução, notas, glossário e bibliografia de Paulo Meneses, Agemir Bavaresco, Alfredo Moraes, Danilo Vaz, Curado R.M. Costa, Greice Ane Barbieri e Paulo Roberto Konzen, São Paulo: Loyola; São Leonardo: Unisinos, 2010.

HÖSLE, Vittorio. Hegels System. Der Idealismus der Subjektivität und das Problem der Intersubjektivität. Bd. 2.: Philosophie der Natur und des Geistes. Hamburg: Meiner, 1988.

HÖSLE, Vittorio. Moral und Politik. Grundlagen einer Politischen Ethik für das 21. Jahrhundert. München: C. H. Beck, 1997.

HÜNING, Dieter. Die "Härte des abstracten Rechts". In: Societas rationis. Festschrift für Burkhard Tuschling zum 65. Geburtstag. Dieter Hüning, Gideon Stiening, Ulrich Vogel (org.). Berlin: Duncker\&Humbolt Verlag, 2002, pp. 255-262.

ILTING, Karl Heinz. Rechtsphilosophie als Phänomenologie der Freiheit. In: Hegels Philosophie des Rechts. Die Theorie der Rechtsformen. Dieter Henrich, Rolf Peter Horstmann (org.). Stuttgart: Klett-Cotta, 1982, pp. 225-254.

KANT, Immanuel. Metaphysik der Sitten. In: Werke in zwölf Bänden. Wilhelm Weischedel (org.). Frankfurt am Main: Suhrkamp, 1968. Bd. VIII.

QUANTE, Michael. ,Die Persönlichkeit des Willens' als Prinzip des abstrakten Rechts. Eine Analyse der begriffslogischen Struktur der $\S \S 34-40$ von Hegels Grundlinien der Philosophie des Rechts. In: G.W.F. Hegel. Grundlinien der Philosophie des Rechts. Ludwig Siep (org.). (Reihe: Klassiker Auslegen. Otfried Höffe (org.). Bd. 9). Berlin: Akademie-Verlag, 1997, pp. 73-94.

REINBACH, Adolf. Die apriorischen Grundlagen des bürgerlichen Rechts. In: Jahrbuch für Philosophie und phänomenologische Forschung 1. Halle a. d. S., 1913, pp. 685-847.

SAVIGNY VON, Carl Friedrich. Das Obligationsrecht als Theil des heutigen Römischen Rechts. Bd. 2. Berlin: Veit, 1853.

SCHAEFER, Márcio Egídio. Bürgerliche Gesellschaft und Staat. Zur Rekonstruktion von Marx' Theorie und Kritik des Staates. Würzburg: Königshausen \& Neumann, 2018.

SCHICK, Friederike. Der Begriff der Person in Hegels Rechtsphilosophie. Überlegungen zu den $\S \S 34-41$ der „Grundlinien der Philosophie des Rechts“. In: Recht ohne Gerechtigkeit? 
Hegel und die Grundlagen des Rechtsstaates. Mirko Wischke, Andrzey Przylebski (org.). Würzburg: Köngshauen \& Neumann, 2010, pp. 65-81.

SCHILDBACH, Ina. Armut als Unrecht. Zur Aktualität von Hegels Perspektive auf Selbstverwirklichung, Armut und Sozialstaat. Bielefeld: Transcritp Verlag, 2018.

SEELMANN, Kurt. Selbstwiderspruch als Grund für Rechtszwang, Fremdbestimmung von Lebenssinn? In: Anfang und Grenzen des Sinns. Brigitte Hilmer, Georg Lohmann, Tilo Wesche (org.). Weilerswist: Velbrück Wissenschaft, 2006, pp. 250-263.

THEUNISSEN, Michael. Die verdrängte Intersubjektivität in Hegels Philosophie des Rechts. In: Hegels Philosophie des Rechts. Die Theorie der Rechtsformen. Dieter Henrich, RolfPeter Horstmann (org.). Stuttgart: Klett-Cotta, 1982, pp. 317-381. 